\title{
PENEGAKAN HUKUM PERATURAN MENTERI KELAUTAN DAN PERIKANAN PELARANGAN PENGGUNAAN PUKAT HELA CANTRANG DI KABUPATEN INDRAMAYU
}

\section{LAW ENFORCEMENT REGULATION OF THE MINISTER OF MARINE AND FISHERIES BANNING THE USE OF HELA CANTRANG IN INDRAMAYU DISTRICT}

\author{
Saeful Kholika, Rahmanisa Faujura ${ }^{b}$
}

\begin{abstract}
ABSTRAK
$\mathrm{T}$ erbitnya Peraturan Menteri Nomor 2/Permen-Kp/2015 Tentang Larangan Penggunaan Alat Penangkapan Ikan Pukat Hela (Trawls) dan Pukat Tarik (Seine Nets) mengatur dan melarang terhadap nelayan di wilayah kelautan Indonesia, implementasinya terdapat pelanggaran. Salah satu permasalahannya adalah masih adanya beberapa nelayan di wilayah kabupaten indramayu yang menggunakan Alat Penangkapan Ikan Pukat Hela (Trawls) dan Pukat Tarik (Seine Nets) yang tentunya merusak ekosistem lingkungan laut, dalam peraturan menteri tersebut haruslah memberikan efek jera terhadap nelayan yang masih melanggar peraturan tersebut. Metode penelitian ini menggunakan metode yuridis normatif, menggunakan data sekunder yang diperoleh dari beberapa studi literatur yang selaras secara kualitatif, hasil penelitian dan diskusi ini merupakan ancaman yang sangat serius dalam penangkapan ikan melalui metode Ikan Pukat Hela (Trawls) dan Pukat Tarik. Sehingga dapat disimpulkan pemerintah dan semua komponen masyarakat haruslah mempunyai sebuah fungsi yang utama guna mencegah dan mengupayakan optimalisasi penegakan hukum.
\end{abstract}

Kata kunci: daerah; ekosistem; hukum; laut; lingkungan.

\begin{abstract}
The issuance of ministerial regulation Number 2/Permen-Kp/2015 Prohibition of the Use of Trawls and Seine 1 Nets regulates and prohibits fishermen in the Indonesian maritime area. Its implementation is a violation, for example there are still some fishermen in the regency indramayu that uses Trawls and Seine Nets which damages the marine environment ecosystem. In this ministerial regulation must provide a deterrent effect for fishermen who still violate these regulations, this research method uses normative juridical methods, using secondary data obtained from several literary studies that are qualitatively harmonious, the results of this research and discussion represent a very serious threat in fish catching through the Trawls and Trawls methods, so that it can be concluded that the Government and all components of the community must have a the main function is to prevent and strive for the optimization of law enforcement.
\end{abstract}

Keywords: region; ecosystem; law; sea; environment.

\footnotetext{
a Fakultas Hukum Universitas Wiralodra Indramayu, Jl. Ir. H. Juanda KM. 03 Singaraja, Indramayu - Jawa Barat 45213, email: saefulkholik21@gmail.com.

b Fakultas Hukum Universitas Wiralodra Indramayu, Jl. Ir. H. Juanda KM. 03 Singaraja, Indramayu - Jawa Barat 45213, email: rahmanisaa@gmail.com.
} 


\section{PENDAHULUAN}

$\mathrm{I}$ ndonesia adalah salah satu negara kepulauan terbesar dengan sumber keanekaragaman hayati maupun nonhayati yang tersebar luas berkat kondisi geografis yang dimilikinya. Dengan luas daratan Indonesia berkisar $1.922 .570 \mathrm{~km}^{2}$ dan luas perairannya yang mencapai $3.257 .483 \mathrm{~km}^{2}$, biota yang hidup dalam perairan tersebut sangat beragam. Ekosistem yang ada pun saling terkait satu sama lain seperti ekosistem karang, ekosistem pasir dan lain-lain. Salah satu ekosistem yang berperan penting sebagai indikator lingkungan yang baik bagi biota laut untuk tumbuh berkembang biak ialah melalui ekosistem terumbu karang.

Pergusuran sumber daya alam (Natural Resource Depletion) dapat diartikan sebagai pemanfaatan sumber daya alam secara tidak bijaksana baik dalam bentuk pengelolaan udara, darat dan laut sehingga sumber daya alam itu baik kualitasnya maupun kuantitasnya menjadi berkurang atau menjadi menurun dan pada akhirnya akan habis dan tidak tersisa sama sekali. Ancaman akan habisnya dan rusaknya sumber daya alam terutama dapat terjadi pada titik lingkungan kelestarian laut daerah yaitu salah satu jenis kerusakan laut yang tidak dapat diperhitungkan pemulihan dan pelestarian laut dan biota laut yang diakibatkan oleh faktor pemanfaatan laut daerah yang tidak dapat dikontrol dengan baik yang pemanfaatannya tidak disertai dengan konservasi yang baik.

Meskipun beberapa jenis sumber daya alam laut tergolong salah satu bentuk kerusakan yang dapat dilakukan atau dipulihkan dengan skema konservasi akan tetapi dalam pertumbuhan ekosistem laut dan sekitarnya tidak dapat diperhitungkan secara cepat dan baik dalam sebuah grafik pertumbuhannya.

Perbedaan pokok antara pencemaran lingkungan dengan kerusakan sumber daya laut adalah bahwa pencemaran dapat terjadi karena masuknya atau hadirnya suatu zat yang dapat berbahaya, energi atau sebuah komponen ke dalam lingkungan hidup atau ekosistem tertentu. Dengan demikian zat, energi, atau komponen itu merupakan suatu yang asing atau yang pada mulanya tidak ada didalam suatu kawasan lingkungan hidup, kemudian hadir dalam kuantitas atau sebuah kualitas tertentu karena dimasukan oleh sebuah kegiatan manusia.

Dampak negatif dari menurunnya atau rusaknya ekosistem dan pelestarian laut secara kualitas dan kuantitas lingkungan hidup baik karena terjadi pencemaran atau kerusakan laut timbulnya ancaman atau dampak negatif terhadap kesehatan, menurunnya estetika laut, biota laut, ekonomi dan yang paling utama adalah terjadinya abrasi serta biota laut yang tidak seimbang. 
Wilayah pesisir merupakan wilayah yang sangat penting ditinjau dari beberapa sudut pandang pencemaran lingkungan. Transisi antara daratan dan lautan membentuk suatu ekosistem laut yang memang secara alamiah dan memberikan nilai ekonomis bagi kebutuhan manusia pada umumnya. Menyadari dengan segala konsekuensinya pemerintah sebagai wadah dalam sebuah institusi memiliki kewenangan untuk menjaga keseimbangan laut yang terdapat di daerah. ${ }^{1}$

Salah satu bentuk kepedulian pemerintah terhadap proses penangkapan ikan yang tidak merusak lingkungan laut atau pengelolaan sumber daya alam laut pemerintah memberikan sebuah perhatian melalui terbitnya Peraturan Menteri Kelautan dan Perikanan Republik Indonesia Nomor 2/Permen-Kp/2015 Larangan Penggunaan Alat Penangkapan Ikan Pukat Hela (trawls) dan Pukat Tarik (seine nets) seharusnya memberikan efek jera akan tetapi masih terdapat beberapa nelayan yang menggunakan pukat tarik yang dilarang oleh peraturan menteri tersebut. Pelarangan penggunaan alat penangkap ikan seperti cantrang dan pukat hela ini akan merusak ekosistem terumbu karang dan biota laut yang akan mati dan merusak kelangsungan hidup biota laut.

Daerah Indramayu adalah salah satu Kabupaten yang terletak pada Provinsi Jawa Barat Indonesia yang memiliki keadaan geografis Kabupaten Indramayu terletak pada $107^{\circ} 52^{\circ}$ $108^{\circ} 36^{\circ}$ Bujur Timur dan $6^{\circ} 15^{\circ}-6^{\circ} 40^{\circ}$ Lintang Selatan. Berdasarkan topografinya sebagian besar merupakan dataran atau daerah landai dengan kemiringan tanahnya rata-rata $0-2 \%$. Keadaan ini berpengaruh terhadap drainase, bila curah hujan cukup tinggi, maka di daerahdaerah tertentu akan terjadi genangan air. Kabupaten Indramayu terletak di pesisir utara Pulau Jawa dan memiliki 10 kecamatan dengan 35 desa yang berbatasan langsung dengan laut dengan panjang garis pantai 114,1 Km. Yang memiliki karakteristis adalah nelayan.

Dengan keadaan geografis dan topografis daerah Indramayu adalah wilayah pantai maka secara tidak langsung memberikan sebuah peluang perikanan dan kelautan hal ini memberikan hasil laut yang sangat melimpah terhadap pekerjaan nelayan. Namun dengan kenyataan yang ada dalam penangkapan ikan yang menggunakan metode pukat hela (trawls) dan pukat tarik (seine nets) berdampak pada ekosistem laut yang rusak. Pemerintah haruslah mampu memberikan sebuah penegakan hukum apabila terjadi sebuah pelanggaran yang dapat dilakukan oleh nelayan yang sangatlah merugikan ekosistem laut ini.

\footnotetext{
${ }^{1}$ Hamuna, Bigo Hamuna; Tanjung, Rosye HR.; Suwito; Maury, Hendra K.; Alianto. 2018. Kajian Kualitas Air Laut Dan Indeks Pencemaran Berdasarkan Parameter Fisika Dan Kimia di Perairan Distrik Depapre Jayapura, Jurnal Ilmu Lingkungan, Vol 16 Issue 1, hlm. 35-43.
} 
Terbitnya Peraturan Menteri Kelautan Dan Perikanan Republik Indonesia Nomor 2/Permen-Kp/2015 Larangan Penggunaan Alat Penangkapan Ikan Pukat Hela (Trawls) dan Pukat Tarik (Seine Nets) seharusnya memberikan efek jera akan tetapi masih terdapat beberapa nelayan yang menggunakan pukat Tarik yang dilarang oleh peraturan menteri tersebut. Pemerintah haruslah mampu memberikan sebuah penegakan hukum apabila terjadi sebuah pelanggaran yang dapat dilakukan oleh nelayan yang sangatlah merugikan ekosistem laut ini. ${ }^{2}$

Implementasi dalam sebuah nilai kenyataan dan keharusan aturan yuridis memberikan sudut pandang permasalahan bahwa bagaimanakah penegakan hukum terhadap nelayan yang masih menggunakan pukat hela dan pukat tarik dikaitkan dengan Peraturan Menteri Nomor 2/Permen-KP/2015 Larangan Penggunaan Alat Penangkapan Ikan Pukat Hela (trawls) dan Pukat Tarik (seine nets) di Kabupaten Indramayu Desa Karangsong? dan upaya dan kendala terhadap nelayan yang masih menggunakan pukat hela dan pukat tarik dikaitkan dengan Peraturan Menteri Nomor 2/Permen-Kp/2015 tentang Larangan Penggunaan Alat Penangkapan Ikan Pukat Hela (trawls) dan Pukat Tarik (seine nets) di Kabupaten Indramayu Desa Karangsong?

Dengan ulasan permasalahan dan identifikasi masalah tentunya artikel ini memiliki tujuan tersendiri salah satunya adalah untuk mengetahui penegakan hukum peraturan bagaimanakah penegakan hukum terhadap nelayan yang masih menggunakan cantrang, pukat hela dan pukat tarik dikaitkan dengan Peraturan Menteri KP Nomor 2/Permen-KP/2015 tentang Larangan Penggunaan Alat Penangkapan Ikan Pukat Hela (trawls) dan Pukat Tarik (seine nets) di Kabupaten Indramayu Desa Karangsong dan untuk mengetahui upaya dan kendala terhadap nelayan yang masih menggunakan pukat hela dan pukat tarik dikaitkan dengan Peraturan Menteri KP tersebut.

\section{METODE PENELITIAN}

Dendekatan masalah yang akan digunakan dalam penelitian ini adalah pendekatan yuridis 1 normatif. Untuk itu diperlukan penelitian yang merupakan suatu rencana pokok dalam pengembangan ilmu pengetahuan. Menurut Soerjono Soekanto pendekatan yuridis normatif yaitu penelitian hukum yang dilakukan dengan cara meneliti bahan pustaka atau data sekunder sebagai bahan dasar untuk diteliti dengan cara mengadakan penelusuran adalah

\footnotetext{
2 http:/ / diskanla.indramayukab.go.id/ Diakses pada Tanggal 30 Mei 2020 Pukul 14.00 WIB.
} 
terhadap peraturan-peraturan dan literatur-literatur yang berkaitan dengan permasalahan yang diteliti. ${ }^{3}$

Melalui tahapan pengumpulan data seperti undang-undang dasar negara republik indonesia, Undang-undang Nomor 9 Tahun 2015 tentang Pemerintahan Daerah, Peraturan Menteri Nomor 2/Permen-KP/2015 tentang Larangan Penggunaan Alat Penangkapan Ikan Pukat Hela (trawls) dan Pukat Tarik (seine nets). Selain itu data diperoleh dari hasil beberapa analisis lingkungan hidup Kabupaten Indramayu.

\section{PEMBAHASAN}

Penegakan Hukum Terhadap Nelayan yang Masih Menggunakan Pukat Hela dan Pukat Tarik Dikaitkan Dengan Peraturan Menteri Nomor 2/Permen-Kp/2015 tentang Larangan Penggunaan Alat Penangkapan Ikan Pukat Hela (Trawls) dan Pukat Tarik (Seine Nets) di Kabupaten Indramayu Desa Karangsong

$\mathrm{R}$ ezim perairan Negara kepulauan atau perairan nusantara yang diakui dalam sebuah konstitusi hukum internasional baru sebagaimana tercantum dalam bagian IV daripada sebuah konvensi hukum laut tahun 1982 mempunyai sebuah arti yang penting bagi Indonesia karena telah membenarkan usaha-usahanya untuk mendapatkan hak kedaulatan atau ekslusif atas kekayaan alam yang terkandung dalam batas-batas kepulauan Indonesia termasuk di dalamnya kekayaan hayati dan kekayaan non-hayati yang terdapat dalam dasar laut dan tanah dibawahnya.

UNCLOS 1982 mengatur penggunaan laut sesuai dengan status hukum zona-zona ini. Negara-negara yang berbatasan dengan laut, termasuk Indonesia memiliki kedaulatan penuh atas perairan daratan, perairan kepulauan, dan laut teritorial. Sebagai zona tambahan, ZEE dan landas kontinen. Negara memiliki hak eksklusif, seperti hak untuk memanfaatkan sumber daya alam di zona tersebut. Adapun laut terbuka, itu adalah zona yang tidak dapat dimiliki oleh Negara mana pun, dan wilayah dasar laut internasional ditetapkan sebagai bagian dari warisan bersama umat manusia. ${ }^{4}$

Pasal 49 Dari konvensi tersebut diatas menetapkan bahawa legal status of archipelagic water of the air space over archipelagic waters and of their bad and subsoil:

\footnotetext{
3 Soekanto, Soerjono dan Mamudji, Sri. 2001. Penelitian Hukum Normatif (Suatu Tinjauan Singkat), Rajawali Pers, Jakarta, hlm. 13-14.

4 Sasvia dan Afifa, Siti. 2019, “Ulasan Hukum Pidana Sanksi pada Terumbu Karang Rusak”, Lex Scientia Law Review. Volume 3 Nomor 2, Mei, hlm. 227-234.
} 
1. The sovereignty of an archipelagic state extends to the waters enclosed by the archipelagic base lines drawn in accordance with article 47, Described as archipelagic waters, Regardless of their depth or distance from the coast

2. This sovereignty extends to the air space over the archipelagic waters as well as to the their bad and sub soil and the resources contained therein

3. This sovereignty is exercised subjet to this part

4. The regime of archipelagic sea lands passage established in the part shall not in other respect affect the status of the archipelagic water, including the sea lanes or the exercise by the archipelagic state of its sovereignty over such waters and their air space, bad and subsoil and the resources contained therein

Tidak kurang pentingnya dibandingkan dengan hak eksklusif atau kekayaan alam yang telah diperoleh itu adalah penetapan sebuah garis garis batas yang telah daripada sebuah wilayah yang ada di bawah yurisdiksi atau kewenangan nasional. Inisiatif Indonesia yang telah diambil sejak tahun 1969 Untuk mengadakan perjanjian perbatasan dengan negara tetangganya yang harus kita lihat dalam rangka atau hubungan ini. Hingga kini telah diadakan enam belas perjanjian perbatasan tidak termasuk perjanjian celah timor yang baru baru ini ditandatangani dengan Australia.

Siombo menyatakan bahwa pada dasarnya, hukum mengatur hubungan antar manusia karena hukum merupakan bagian dari sistem sosial yang ada dalam masyarakat. Hukum dan masyarakat adalah satu kesatuan yang tidak bisa dipisahkan. Republik Indonesia adalah negara kepulauan dengan wawasan kepulauan. Secara geografis, keberadaan pulau-pulau yang tersebar di wilayah Indonesia sangat strategis. Karena berdasarkan pulau-pulau ini batasbatas negara ditentukan. ${ }^{5}$

Hukum laut baru ini juga mengakui wewenang atas kekayaan alam yang berada di luar laut teritorial, perjanjian-perjanjian landas dasar laut dan perjanjian batas laut teritorial. Ditetapkannya hak atau wewenang yang luas atas laut disekitar kepulauan berdasarkan rezim hukum nergara kepulauan yang berlaku sejak dikeluarkannya Deklarasi Juanda tanggal 13 desember 1957 yang kemudian disusul oleh perjanjian-perjanjian penetapan batas atau perbatasan dengan negara tetangga telah mengamankan kepentingan eksklusif indonesia atas segala kekayaan alam, baik hayati maupun non-hayati yang terdapat didalam garis-garis batas kini.

5 Ria, M. Siombo. 2010. Hukum Perikanan Nasional dan Internasional, PT Gramedia Pustaka Utama, Jakarta, hlm. 43. 
Kekayaan alam itu merupakan suatu potensi besar yang baru diambil untuk sebagian saja, sebagian besar berupa kekayaan hayati laut (perikanan). Di satu pihak kekayaan alam yang diperoleh dengan perluasan kedaulatan atas perairan kepulauan itu merupakan penambahan pada kekayaan alam yang terdapat di daratan. Namun di pihak lain potensi kekayaan alam di laut ini juga mengandung beberapa masalah. Satu masalah yang dihadapi adalah untuk membagi kekayaan alam itu dengan pihak-pihak lain yang juga menginginkan atau mempunyai tuntutan atas kekayaan alam itu. Perundingan dan kemudian penandatangan perjanjian-perjanjian perbatasan dengan Negara-negara tetangga seperti, Malaysia, Singapura, Thailand, India, PNG, dan Australia yang telah memecahkan masalah itu untuk sebagian.

Dikatakan secara sebagian karena perjanjian perbatasan demikian hanya efektif secara mutlak berkenaan dengan kekayaan mineral atau minyak dan gas bumi. Sedangkan mengenai kekayaan hayati laut, perjanjian-perjanjian perbatasan demikian hanya setengah efektif karena ikan yang bergerak tidak mengakui bahkan tidak mengetahui adanya perjanjian-perjanjian yang telah disetujui antara negara, tidak seperti perusahan-perusahaan yang mengadakan ekpsplorasi atau penggalian kekayaan mineral atau minyak dan gas bumi. Dengan perkataan lain bertalian dengan kekayaan hayati laut terutama ikan yang bergerak bebas mungkin diperlukan lain-lain perjanjian disamping perjanjian perbatasan.

Pemanfataan yang optimal tercapai apabila dalam daerah lingkungan laut yang sudah dicadangkan untuk kepentingan nasional itu kita mampu mengerahkan kemampuan penggalian kekayaan yang optimal. Dalam hal kita tidak dapat mengerjakan sendiri kita dapat mengundang pihak luar untuk pengambilan kekayaan alam kita. Untuk keperluan inilah kita memerlukan pengembangan konsep-konsep pengambilan kekayaan dan pengelolaan. Sepanjang mengenai kekayaan non-hayati atau mineral kita telah memiliki konsep kontrak karya dan production sharing.

Gangguan terhadap kekayaan optimal terjadi apabila lingkungan laut itu mengalami pemburukan (degradation) sehingga pengembangan potensi kekayaan hayati tidak saja terganggu perkembangannya tetapi bahkan bisa menurun. Pemburukan lingkungan laut juga akan tidak memungkinkan pengembangan atau pengambilan kekayaan hayati secara kesinambungan. Karena itu tidak kurang pentingnya dibandingkan dengan penetapan garisgaris batas wilayah dan yurisdiksi nasional adalah masalah perlindungan dan pelestarian lingkungan laut sebagai wadah kekayaan alam yang hendak kita gali dan kita kembangkan secara kesinambungan. 
Deklarasi Stockholm 1972 merupakan pilar perkembangan hukum lingkungan internasional modern, artinya semenjak saat itu hukum lingkungan berubah sifatnya dari useoriented menjadi environment-oriented. Hukum lingkungan yang bersifat Use-Oriented maksudnya adalah produk hukum yang melulu memberikan hak kepada masyarakat internasional untuk mengeksploitasi lingkungan dan sumber daya alam tanpa membebani dan berkewajiban untuk menjaga, melindungi, dan melestarikannya. Dengan kata lain produk hukum yang ada sebelum lahirnya deklarasi Stockholm hanya menjustifikasi hak manusia untuk memakai lingkungan seperti konvensi hukum laut 1958 secara umum hanya memberikan hak kepada negara untuk mengambil sumber daya alam kelautan, akan tetapi ini tidak diwajibkan negara untuk menjaga laut dari tindakan pencemaran dan perusakan. ${ }^{6}$

Menurut Takdir Rahmadi, penegakan hukum lingkungan dapat dimaknai sebagai penggunaan atau penerapan instrumen-instrumen dan sanksi-sanksi dalam lapangan hukum administrasi, pidana, atau perdata dengan tujuan memaksa subjek hukum yang menjadi sasaran untuk mematuhi Peraturan Perundang-undangan lingkungan hidup. ${ }^{7}$

Penegakan hukum dan peraturan yang mengatur aktivitas-aktivitas di perairan laut dan pesisir Indonesia dilakukan oleh beberapa lembaga pemerintah secara bersama-sama dalam kegiatan eksplorasi, eksploitasi dan konservasi sumberdaya alam laut di kawasan laut dan pesisir, terdapat dua kementerian utama yang bertanggung jawab dalam penegakan hukum. Kedua departemen pemerintah tersebut adalah kementerian kelautan dan perikanan. Direktorat Jenderal Pengawasan Sumberdaya Laut dan Perikanan (DITJEN PSLP) adalah jabatan setingkat eselon I di DKP yang bertanggung jawab dan berfungsi untuk melaksanakan kegiatan pemantauan (monitoring), pengawasan (control), pengintaian/pengamatan (surveillance) dan penegakan hukum (enforcement) dari peraturan-peraturan yang berkaitan dengan pengelolaan sumberdaya ikan dan sumberdaya alam laut lainnya dalam melaksanakan tugas dan fungsinya. ${ }^{8}$

Mengacu pada hal itu bahwa kerusakan lingkungan laut yang diakibatkan media menangkap ikan di Indramayu yang akan berdampak kepada terumbu karang dan ekosistem laut lainya, komponen penegakan hukum haruslah bekerja keras untuk menegakan nilai nilai

6 L. Oppenheim, 1995, Internasional Law, (Ed. By H Lauterpacht) Vol. 1 Edisi VIII, Longmans, London, hlm. 346.

7 Zulfadli, Muhammad Dkk. 2016. Penegakan Hukum Yang Responsif dan Berkeadilan Sebagai Instrumen Perubahan Sosial Untuk Membentuk Karakter Bangsa, Dalam Seminar Nasional Pendidikan Ilmu-Ilmu Sosial Membentuk Karakter Bangsa Dalam Rangka Daya Saing Global" Kerjasama: Fakultas Ilmu Sosial Universitas Negeri Makassar dan Himpunan Sarjana Pendidikan Ilmu-Ilmu Sosial Indonesia Grand Clarion Hotel, Makassar, hlm. 25.

8 Dirhamsyah, 2007, "Penegakan Hukum Laut di Indonesia”, Jurnal Oseana, Volume XXXII, Nomor 1, hlm. 1 -13. 
keadilan terhadap perusak dan nelayan yang masih menggunakan pukat hela dan cantrang yang jelas-jelas dilarang dalam Peraturan Menteri Perikanan Republik Indonesia.

Penerapan sanksi hukum yang belum dapat dirasakan dan terlihat kepada nelayan yang telah melakukan tindakan penangkapan ikan yang masih saja menggunakan pukat hela dan cantrang. Melihat hukum yang masih belum bekerja secara maksimal terdapat beberapa faktor yang mempengaruhi sistem penegakan hukum.

Secara konseptual arti dari sebuah penegakan hukum terletak pada kegiatan menyelesaikan hubungan nilai-nilai yang terjabarkan di dalam kaidah-kaidah yang mantap dan mengutamakan sikap tindak sebagai rangkaian penjabaran nilai tahap akhir untuk menciptakan, memelihara, dan mempertahankan kedamaian pergaulan hidup. Konsepsi yang mempunyai dasar filosofis tersebut, memerlukan penjelasan lebih lanjut, sehingga akan tampak lebih konkret

Penegakan hukum sebagai suatu proses, pada hakikatnya merupakan penerapan diskresi yang menyangkut membuat keputusan yang tidak secara ketat diatur oleh sebuah kaidah hukum, akan tetapi mempunyai unsur penilaian pribadi, dengan hal ini mengutip pendapat dari Roscoe Pound, Maka LaFavre menyatakan bahwa pada hakikatnya diskresi berada diantara hukum dan moral yang dapat mempengaruhi faktor penegakan hukum sebagai berikut:

1. Undang-Undang

Penentuan penegakan hukum di lingkup nasional maupun daerah yang paling utama adalah produk hukum atau undang-undang itu sendiri yang memberikan sebuah aturan dan pola dalam pelaksanaan pengaturan hidup dan ketertiban hukum yang berlaku.

Pembuatan undang-undang atau bahkan peraturan lainnya terkadang tidak diikutinya asas berlakunya undang-undang, belum adanya peraturan pelaksanaan yang sangat dibutuhkan untuk menerapkan undang-undang serta permainan politik dalam pembuatan peraturan tersebut yang hanya menguntungkan salah satu golongan saja. ${ }^{9}$

2. Penegak Hukum

Faktor berikutnya adalah penegak hukum sendiri yang secara sosiologis maka setiap penegak hukum tersebut mempunyai kedudukan status dan peranan seperti kedudukan sosial merupakan sebuah posisi tertentu didalam struktur kemasyarakatan yang sedang dan rendah, kedudukan tersebutlah sangat mempengaruhi sebuah penerapan dan penegakan

9 Purbacaraka, Purandi dan Soekanto, Soerjono. 1993 Renungan Tentang Filsafat Hukum, Jakarta, C.V. Rajawali. hlm. 44. 
hukum bahwasanya penegak hukum haruslah independensi terhadap kasus yang berlandaskan nilai-nilai keadilan.

Penegak hukum menjadi titik celah terhadap penegakan hukum yang berlandaskan keadilan yang berorientasikan mencapai tujuan sebagaimana ditetapkan oleh pembentuk hukum, peran aktual dari penegak hukum berorientasi kepada tujuan hukum itu sendiri. ${ }^{10}$

3. Sarana Atau Fasilitas

Sarana dalam proses penegakan hukum yang berlaku adalah sarana dan prasarana fasilitas tertentu menjadi pembahasan karena apabila dalam penegakan hukum dalam menunjang tidak secara maksimal dan baik maka tidak mungkin penegakan hukum akan berlangsung dengan lancar.

Faktor diatas mencakup ruang lingkup yang sangatlah luas, akan tetapi memang demikianlah halnya apabila hal tersebut dihubungkan dengan sebuah kenyataan yang ada haruslah sesuai dengan nilai-nilai etika sarana dan prasarana11

Dengan demikian dapatlah disimpulkan, bahwa faktor sarana dan fasilitas mempunyai peranan yang sangatlah penting dalam sebuah penegakan hukum tanpa adanya sarana atau fasilitas tersebut tidaklah mungkin penegak hukum menyerasikan peranan yang seharusnya dengan peran yang berlaku.

4. Masyarakat

Penegakan hukum berasal dari masyarakat dan bertujuan untuk mencapai kedamaian didalam masyarakat oleh karena itu, dipandang dari sudut tertentu maka masyarakat dapat mempengaruhi penegakan hukum tersebut.

Dari sudut sistem sosial dan budaya Indonesia memiliki sebuah ciri tersendiri dan majemuk yang terdapat sebuah golongan etnik yang sangatlah berbeda dan kebudayaankebudayaan khusus yang akan berpengaruh kepada pola dan bentuk penegakan hukum yang ada didalam masyarakat.

5. Kebudayaan

Faktor kebudayaan sebenarnya bersatu padu dengan faktor masyarakat yang sengaja dibedakan karena dalam pemahaman dan pembahasanya mengenyampingkan masalah nilai-nilai yang menjadi inti dari sebuah kebudayaan spiritual atau non-material. Sebagai suatu sistem atau suatu kebiasaan dari sub sistem kemasyarakatan maka hukum mencangkup struktur, substansi, dan kebudayaan.

\footnotetext{
10 Pound, Roscoe, 1993, Interpretations Of Legal History, hlm. 67.

11 Ponser, Richard. 1997, Economic Analysis Of Law, Boston Little. Brown And Company, hlm. 41.
} 
Faktor kebudayaan mendorong nilai konservatisme dan nilai inovatif senantiasa berperan dalam perkembangan hukum, oleh karena suatu pihak terdapat menyatakan bahwa hukum hanya mengikuti perubahan yang terjadi dan bertujuan untuk mempertahankan "status quo".

Faktor yang dijelaskan diatas adalah beberapa faktor yang memang terjadi ketika penegakan hukum yang sangat sulit dilakukan dalam lingkup daerah mengingat bahwa masyarakat mempunyai karakteristik masyarakat yang mementingkan golongan dan budaya tersendiri yang dijelaskan oleh Lawrance M. Freidman. ${ }^{12}$

Peraturan Menteri Nomor 2/Permen-Kp/2015 tentang Larangan Penggunaan Alat Penangkapan Ikan Pukat Hela (Trawls) dan Pukat Tarik (Seine Nets) dalam Pasal 2 setiap orang dilarang menggunakan alat penangkapan ikan pukat hela (trawls) dan alat penangkapan ikan pukat tarik (seine nets) di seluruh wilayah pengelolaan perikanan negara Republik Indonesia. Penegakan hukum terhadap nelayan yang masih menggunakan pukat hela dan pukat tarik dikaitkan dengan di kabupaten indramayu desa karangsong masih belum dapat dilaksanakan atau peraturan ini belum dapat berjalan seutuhnya karena aturan dan sanksi dalam peraturan tidak terdapat sanksi secara pasti.

\section{Upaya dan Kendala Terhadap Nelayan yang Masih Menggunakan Pukat Hela dan Pukat} Tarik Dikaitkan dengan Peraturan Menteri Nomor 2/Permen-Kp/2015 Tentang Larangan Penggunaan Alat Penangkapan Ikan Pukat Hela (Trawls) dan Pukat Tarik (Seine Nets) di Kabupaten Indramayu Desa Karangsong.

W ilayah laut Indonesia mengokupasi lebih dari dua pertiga keseluruhan wilayah Republik Indonesia. Laut memberikan berbagai sumber kekayaan alam, baik hayati maupun non hayati bagi Indonesia. Agar aktifitas manusia tidak menimbulkan kerusakan pada mutu air laut, Pemerintah memandang perlu membuat suatu peraturan di bidang pencegahan dan pengendalian pencemaran laut, yang bertujuan untuk memberikan manfaat yang sebesar-besarnya bagi kesejahteraan rakyat dan kelangsungan hidup makhluk hidup lainnya, baik masa sekarang maupun masa yang akan datang. Peraturan Pemerintah Nomor 19 Tahun 1999 tentang pengendalian pencemaran dan atau perusak laut, yang diundangkan pada tanggal 27 Februari tahun 1999, merupakan peraturan yang mengatur pembatasan

12 Friedman, Lawrance, M. 1999, Law And Society. An Introduction. Englewood Cliffs. N.J. Prentice, hlm. 59. 
kegiatan manusia termasuk industri yang dapat menimbulkan pencemaran dan atau perusakan mutu laut.

Untuk mempermudah pemahaman terhadap Peraturan Pemerintah Nomor 19 Tahun 1999, perlu terlebih dahulu memahami arti perusakan laut. Pencemaran laut dapat diartikan sebagai masuknya atau dimasukkannya makhluk hidup, zat, energi, dan atau komponen lain kedalam lingkungan laut oleh kegiatan manusia, baik di darat maupun di laut sehingga kualitas laut turun sampai ketingkat tertentu yang menyebabkan lingkungan laut tidak sesuai lagi dengan baku mutu dan atau fungsinya. Adapun perusakan laut didefinisikan sebagai tindakan manusia, baik di darat maupun di laut yang menimbulkan banyak perubahan, baik langsung maupun tidak langsung terhadap sifat fisik dan atau hayati laut yang melampaui kriteria baku kerusakan laut.

Peraturan Pemerintah Nomor 19 Tahun 1999 dirancang untuk melindungi mutu laut, yang meliputi upaya atau kegiatan pengendalian pencemaran dan atau perusakan laut dengan tujuan untuk mencegah atau mengurangi turunnya mutu laut dan atau rusaknya sumber daya laut. Perlindungan mutu laut harus didasarkan pada baku mutu air laut, kriteria baku kerusakan laut dan status mutu laut.

Baku mutu air laut dan kriteria baku kerusakan air laut ditetapkan oleh menteri dengan mempertimbangkan masukan dari menteri lainnya dan pimpinan lembaga pemerintah non departemen terkait lainnya. Adapun status mutu laut ditetapkan oleh Gubernur berdasarkan inventarisasi dan atau penelitian data mutu air laut, kondisi tingkat kerusakan laut yang mempengaruhi mutu laut. Apabila Gubernur tidak menempatkan status mutu laut, maka kepala instansi yang bertanggung jawab harus menetapkan status mutu laut.

Analisis Dampak lingkungan (AMDAL), Telah secara luas digunakan oleh banyak Negara sesuai dengan instrumen hukum yang berlaku bagi setiap negaranya untuk mencegah terjadinya pencemaran lingkungan dari suatu fasilitas, Analisis dampak lingkungan merupakan studi analisis guna mencegah terjadinya kerusakan lingkungan yang berorientasikan kepada pembangunan yang didasarkan konsep ekologi.13

Dalam upaya mencegah pencemaran laut, setiap orang atau penanggung jawab usaha dan atau kegiatan tidak boleh melakukan perbuatan yang dapat menimbulkan pencemaran laut. Oleh karena itu, penanggung jawab kegiatan yang harus membuang limbahnya ke laut, harus memenuhi persyaratan mengenai baku mutu air laut, baku mutu limbah cair, baku mutu

${ }^{13}$ Friedman, Frank B, 1993, Practical Guide To Environmental Management. Washington.D.C. Environmental Law Institute, hlm. 261. 
emisi dan ketentuan-ketentuan lainnya sesuai dengan peraturan perundang-undangan yang berlaku. Penanggung jawab diwajibkan melakukan pencegahan pencemaran laut.

Untuk mencegah perusakan laut, Pasal 13 Peraturan Pemerintah Nomor 19 Tahun 1999 menggariskan bahwa orang atau penanggung jawab usaha dan atau kegiatan tidak boleh dilakukan perbuatan yang dapat menimbulkan kerusakan laut. Lebih lanjut dalam Pasal 14 dikatakan bahwa penanggung jawab usaha dan atau kegiatan yang dapat mengakibatkan terjadinya kerusakan laut diharuskan melakukan upaya pencegahan perusakan laut. Adapun bila kegiatannya telah menimbulkan pencemaran laut, Pasal 15 mengharuskan penanggung jawab kegiatan untuk melakukan upaya penanggulangan pencemaran dan atau perusakan laut yang diakibatkan oleh kegiatannya.

Kegiatan yang menimbulkan limbah cair dan atau limbah padat dari kegiatan rutin operasional di laut, Penanggung jawabnya diwajibkan untuk mengelola dan membuang limbah di sarana pengelolaan limbah cair dan atau limbah padat sesuai dengan peraturan perundang-undangan yang berlaku. akan tetapi, dalam keadaan darurat, pembuangan benda ke laut yang berasal dari usaha dan atau kegiatan di laut dapat dilakukan tanpa izin, apabila:

1. Pembuangan benda dimaksudkan untuk menjamin keselamatan jiwa kegiatan di laut.

2. Pembuangan benda dimaksud disebabkan oleh adanya kerusakan pada peralatannya dengan syarat bahwa semua upaya pencegahan yang layak telah dilakukan atau pembuangan tersebut merupakan cara terbaik untuk mencegah kerugian yang lebih besar dalam keadaan demikian, penanggung jawab usaha dan atau kegiatan harus segera memberitahukan kepada pejabat yang berwenang dan atau instansi yang bertanggung jawab. Pemberitahuan sebagaimana dimaksud pada ayat 2 diatas, wajib menyebutkan tentang benda yang dibuang, lokasi, waktu, jumlah, dan langkah-langkah yang telah dilakukan.

Peraturan Pemerintah Nomor 19 Tahun 1999 juga merupakan instrumen untuk menerapkan konvensi hukum laut tahun 1982 yang melarang perbuatan mendumping bendabenda ke laut. Pasal 18 Peraturan Pemerintah Nomor 19 Tahun 1999 melarang orang atau penanggung jawab usaha dan atau kegiatan untuk melakukan dumping ke laut kecuali bila dia telah mendapat izin Menteri.

Dalam perkembangan hukum positif yang berlaku khususnya dalam lingkup perairan laut daerah Kabupaten Indramayu guna mencegah terjadi eksploitasi dan pencemaran lingkungan yang dilakukan oleh oknum dalam sebuah proses pengambilan ikan yang masih menggunakan pukat hela dan pukat Tarik salah satu upayanya adalah tunduk dengan aturan 
pemerintah Peraturan Menteri Nomor 2/Permen-Kp/2015 tentang Larangan Penggunaan Alat Penangkapan Ikan Pukat Hela (trawls) dan Pukat Tarik (seine nets) yang melarang praktik tersebut dituangkan dalam pasal 2 yang menyebutkan bahwa:

“Setiap orang dilarang menggunakan alat penangkapan ikan pukat hela (trawls) dan alat penangkapan ikan pukat tarik (seine nets) di seluruh Wilayah Pengelolaan Perikanan Negara Republik Indonesia".

Selain itu juga pemerintah Kabupaten Indramayu dalam mencegah kegiatan yang dilarang dengan peraturan pemerintahan tersebut terus melakukan sosialisasi dan pemantauan monitoring dalam pelaksanaan izin berlayar kapal yang akan menangkap ikan.

Adapun kendala yang dihadapi oleh Pemerintah Kabupaten Indramayu dalam penegakan hukum lingkungan bagi oknum yang mengambil ikan menggunakan Pukat Hela (trawls) dan Pukat Tarik (seine nets) adalah masih adanya sistem budaya yang menganggap permainan oknum itu diperlukan serta respon atau peran masyarakat untuk melaporkan kejadian masih kurang responsif.

\section{PENUTUP}

\section{Kesimpulan}

Denegakan hukum terhadap oknum yang menggunakan Pukat Hela (trawls) dan Pukat
Tarik (Seine Nets) memang bagaikan dua sisi mata uang yang saling berkaitan dengan sebuah praktik keadilan dan penegakan tersebut di sisi lain masyarakat pantai atau nelayan merasa dengan menggunakan alat tersebut sangatlah menguntungkan pendapatan ikan tersebut akan tetapi sisi lainya menunjukan bahwa terdapat konsekuensi bahwa dengan menggunakan alat tersebut merusak ekosistem laut terutama terumbu karang, Disinilah peran masyarakat dan pemerintah sebagai garda depan harus tegas dan mampu menegakan hukum yang berlaku dan memberikan efek jera terhadap pelaku yang melanggar ketentuan yang berlaku.

Dalam upaya mencegah pencemaran laut Pemerintah Kabupaten Indramayu telah menerbitkan Peraturan Daerah Nomor 14 Tahun 2006 tentang Pengelolaan Pelestarian Kawasan Konservasi Laut Daerah dalam Perlindungan Pulau Pariwisata Kabupaten Indramayu guna memberikan sanksi yang tegas kepada orang maupun lembaga yang telah mencemarkan lingkungan laut, setiap orang atau penanggung jawab usaha dan atau kegiatan tidak boleh melakukan perbuatan yang dapat menimbulkan pencemaran laut. Adapun kendala yang dihadapi oleh pemerintah kabupaten indramayu dalam penegakan hukum 
lingkungan bagi oknum yang mengambil ikan menggunakan Pukat Hela (trawls) dan Pukat Tarik (seine nets) adalah masih adanya sistem budaya yang menggangap permainan oknum itu diperlukan serta respon atau peran masyarakat untuk melaporkan kejadian masih kurang responsif.

\section{Saran}

Denegakan hukum lingkungan laut di daerah memang masih dianggap tabu bagi setiap 1 kalangan yang memang belum mempunyai kesadaran penuh terhadap keberlangsungan ekosistem laut daerah munculnya Peraturan Menteri Nomor 2/Permen-Kp/2015 tentang Larangan Penggunaan Alat Penangkapan Ikan Pukat Hela (trawls) dan Pukat Tarik (seine nets) yang melarang praktik tersebut tidak semata-mata membuat para nelayan Desa Karangsong Kabupaten Indramayu menjadi sebuah acuan dalam menangkap ikan di lautan tentunya apabila hal ini tetap dilakukan maka akan mengancam ekosistem laut daerah. Selaras dengan hasil beberapa penelitian ini diharapkan kepada Pemerintah Daerah Kabupaten Indramayu dan Masyarakat Desa Karangsong Kabupaten Indramayu sadar hukum lingkungan laut daerah dan bersama-sama untuk menjaga kelestarian lingkungan luar daerah sesuai dengan aturan hukum yang berlaku.

\section{DAFTAR PUSTAKA}

\section{Buku}

Friedman, Frank B, 1993, Practical Guide To Environmental Management. Washington.D.C. Environmental Law Institute;

Friedman, Lawrance, M. 1999, Law And Society. An Introduction. Englewood Cliffs. N.J. Prentice;

Muhammad Zulfadli Dkk, 2016, Penegakan Hukum Yang Responsif Dan Berkeadilan Sebagai Instrumen Perubahan Sosial Untuk Membentuk Karakter Bangsa, Dalam Seminar Nasional Pendidikan Ilmu-Ilmu Sosial Membentuk Karakter Bangsa Dalam Rangka Daya Saing Global" Kerjasama: Fakultas Ilmu Sosial Universitas Negeri Makassar Dan Himpunan Sarjana Pendidikan Ilmu-Ilmu Sosial Indonesia Grand Clarion Hotel, Makassar;

M, Siombo Ria, 2010. Hukum Perikanan Nasional dan Internasional, PT Gramedia Pustaka Utama, Jakarta;

Ponser, Richard. 1997, Economic Analysis Of Law, Boston Little. Brown And Company; 
Purnadi Purbacaraka \& Soerjono Soekanto, 1993 Renungan Tentang Filsafat Hukum, Jakarta, C.V. Rajawali;

Pound, Roscoe, 1993, Interpretations Of Legal History;

Soerjono Soekanto \& Sri Mamudji, 2001, Penelitian Hukum Normatif (Suatu Tinjauan Singkat), Rajawali Pers, Jakarta.

\section{Jurnal}

Dirhamsyah, 2007, "Penegakan Hukum Laut di Indonesia”, Jurnal Oseana, Volume XXXII, Nomor 1, Tahun 2007;

Bigo Hamuna, Rosye HR Tanjung, Suwito, Hendra K Maury, Alianto, 2018, “Kajian Kualitas Air Laut Dan Indeks Pencemaran Berdasarkan Parameter Fisika dan Kimia di Perairan Distrik Depapre Jayapura", Jurnal Ilmu Lingkungan, Vol 16 Issue 1;

L.Oppenheim, 1995, “Internasional Law”, (Ed. By H Lauterpacht) Vol. 1 Edisi VIII, Longmans, London;

Philippe Sands, 1995, "Principles Of International Environmental Law", Vol. I, Frameworks, Standards And Implementation, Manchester University Press, Manchester;

Sasvia, Siti Afifa, 2019, “Ulasan Hukum Pidana Sanksi pada Terumbu Karang Rusak”, Lex Scientia Law Review. Volume 3 Nomor 2, Mei.

\section{Sumber Lain}

http://diskanla.indramayukab.go.id/ Diakses pada tanggal 30 Mei 2020 Pukul 14.00 WIB. 